\title{
Trichomes are effective attributes against folivory in areas of secondary forest in ecotone Cerrado-Caatinga
}

\section{Tricomas são atributos efetivos contra folivoria em áreas de mata secundária em ecótono Cerrado-Caatinga}

\author{
Guilherme Santana Lustosa 1 , Daniel Silas Veras 2 \\ ${ }^{1}$ Laboratório de Ecologia de Comunidades, Instituto Federal de Educação, Ciência e Tecnologia do Maranhão/IFMA, Caxias, Maranhão, \\ Brasil. E-mail: Guilherme.lustosa@ifma.edu.br *Autor para correspondência \\ 'Laboratório de Ecologia de Comunidades, Instituto Federal de Educação, Ciência e Tecnologia do Maranhão/IFMA, Caxias, Maranhão, \\ Brasil.E-mail: gustavogomes@aluno.uema.br
}

\author{
Palavras-chave \\ Defesa Mecânica \\ Herbivoria \\ Interação ecológica
}

\section{Keywords}

Mechanical Defense Herbivory

Ecological interaction

\begin{abstract}
Ecossistemas que apresentam maior heterogeneidade tendem a ter uma maior quantidade de interações entre os organismos que fazem parte de suas cadeias tróficas, dentre essas relações temos as de herbivoria, nesse sentido o presente estudo teve por objetivo avaliar a preferência alimentar em herbivoria de plantas por insetos em uma área de fitofisionomia de capoeira, a hipótese testada é de que os insetos preferem plantas com menor quantidade de tricomas. O levantamento foi realizado no Instituto Federal do Maranhão Campus Caxias, no mês de novembro de 2016, nesse período foram amostradas 600 fol has de diferentes espécies, das quais a maior parte não apresentou pilosidade, o teste de associação por qui-quadrado indicou que para plantas presentes na capoeira há uma maior folivoria para aquelas que não apresentam tricomas sobre seu limbo foliar.
\end{abstract}

Ecosystems that show greatest heterogeneity have a greater amount of interactions between organisms that are part of their food chains, among these relationships exists the herbivory, thus the present study aims to evaluate the feeding preference of herbivory insects for plants in an area of capoeira vegetation, the hypothesis tested is that insects prefer plants with less trichomes. The survey was performed at the Federal Institute of Maranhão Campus Caxias, in November 2016, during which 600 leaves of different species were sampled, most of which did not show pilosity, and the association test by chi-square indicated that for plants present in "capoeira" there are a greater folivory for those that do not present trichomes on its leaf limb.

\section{INTRODUCTION}

Brazilian Cerrado is the second largest phyto physiographic domain of Brazil, being recognized as a biodiversity hotspot, especially considering the diversity of their phytophysiognomies (Oliveira et al. 2017; Silva; Veras; Chaves, 2017), this domain undergoes natural and human pressures. Among the human activities, replacement of the primary vegetation for cultivation of different crops that are later abandoned and in these areas through a succession process there is a formation of a secondary forest (Salomão et al. 2012), this feature enables the development of a large number of niche, inclusive of different strategies of herbivory (Price, 2002). Especially considering that many organisms, including insects cause damage to structures like the leaves that are important attributes for the metabolism of the plants (Sato; Ito; Kudoh, 2017), because of this, the different herbivores must overcome physical and chemical defenses of plants (Lopresti et al. 2018), which indicates a history of co- evolution of strategies between of these organisms.

These defenses can be based on different strategies, such as mechanical structures in the cuticle or epidermis, may also be epidermal appendages, as well as chemical protection by producing secondary metabolites (Lopresti et al. 2018; Bartimachi; Neves; Vasconcelos, 2015). Among the various strategies available, one of widely studied is the presence of trichomes on the leaf surface, which is one of the characters better distributed in different plant taxa (Mannethody; Purayidathkandy, 2018), this structure has been shown as an important tool against the action of herbivorous insects in various plant crops (Tian et al 2012; Løe et al 2007).

Considering the above, this study aimed to evaluate the feeding preference of herbivory insects for plants in an area of phytophysiognomy of Capoeira. The tested hypothesis is that insects prefer plants with smaller amount of trichomes because they confer less mechanical and / or chemical resistance to the action of the insects. 


\section{METHODOLOGY}

The municipality Caxias is in a transition area between the Brazilian Cerrado and Caatinga, the mean annual temperature is around $28^{\circ} \mathrm{C}$, while the precipitation is between 1,100 to $1,800 \mathrm{~mm}$. It has two distinct seasons, from December to April rainy season and from July to November dry season (Medeiros, 2015). The a predominant vegetation type in the municipality is the semideciduous seasonal forest (Peixoto Neto, Lima, Araújo, Chaves, \& Siqueira, 2016), with predominance of the plant species Attalea speciosa, in some stretches the Attalea speciosa ceases to exist and in these stretches, it is observed Cerrado and Cerradão. This research was conducted at the Federal Institute of Maranhão Campus Caxias, in the state of Maranhão (Figure 1).

Figure 1. Location of the Federal Institute of Maranhão Campus Caxias, Maranhão, Brazil.

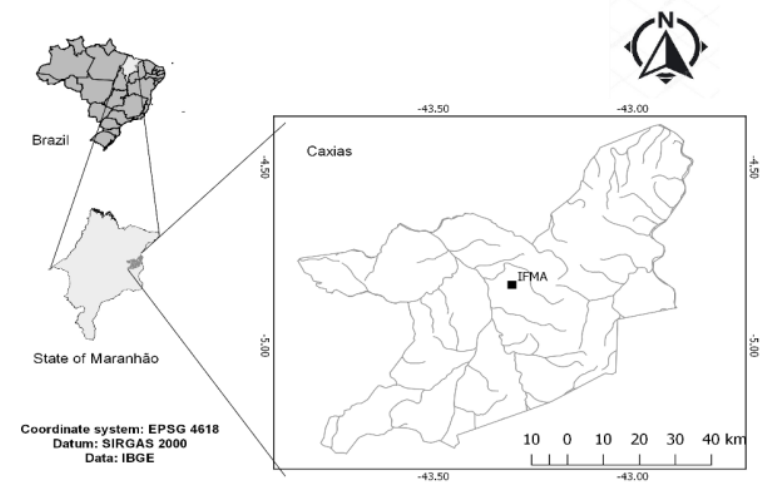

The study was carried out in November 2016, sampling was performed along a transect of 500 meters, in which each 25 meters was established a perpendicular transect 5 meters, in which were randomly observed 30 leaves of plant species in which the limbus of the leaf was observed and verified if there was presence or absence of hairs and presence of foliar herbivory (folivoria). For the statistical analysis, the chi-square association test was used to carry out the test. The assumptions of the test were taken into account. The analysis was performed with a $95 \%$ confidence interval in the statistical environment R ( $R$ Development Core Team, 2016).

\section{RESULTS AND DISCUSSION}

In a total of 600 leaves that were sampled, 474 (79\%) presented no trichomes and $126(21 \%)$ presented trichomes. It was observed the predominated of herbivory in the leaves with trichomes absence. About $35.7 \%$ of the samples had folivory, being $85.05 \%$ with absence of the trichomes and $14.95 \%$ had trichomes, while $64.3 \%$ of the showed no herbivory, being $61.6 \%$ without trichomes, and $48.4 \%$ with trichomes. There was association between variables $(\chi 2=$ $6.775 ; \mathrm{df}=1 ; \mathrm{p}=0.009$ ). As observed herbivory values for leaves without trichomes were higher than expected, we conclude that there is a greater preference for leaf consumption without this attribute when compared to leaves presenting them.

Our results corroborate with other studies that indicate that the presence of trichomes on the leaf surface provide an effective means of protection against the action of herbivorous insects (TOZIN; MARQUES; RODRIGUES, 2017; $L \varnothing E$ et al., 2007). This defense can be improved if there is the presence of abrasive material in the edible parts of plants, as this can lead to reduction in the digestibility or preference for the taxa having these strategies (LOPRESTI et al., 2018), or as a result of the production of substances that can reduce the ability of insects to perform their digestive processes (AOYAMA; LABINAS, 2012). In addition, the presence of glandular trichomes may potentiate the defense of the plant when they allow a mutual interaction with organisms that protect the plant against others that are herbivores (BARTIMACHI; NEVES; VASCONCELOS, 2015).

The results indicate that for this researched region it is interesting to adopt a culture that preferably has this strategy of defense against folivore, since the use of crops that do not express resistance to herbivore attack will lead to productivity loss (Corrêa et al. 2008; Barônio, 2012), which causes degradation of the ecosystems, because of the use pesticides for the control of the populations of organisms called pests (Karley et al. 2015).

\section{CONCLUSION}

Folivory was associated more with the leaves with less pilosity, corroborating with our hypothesis, pointing out that this mechanism consists of an important strategy for resistance to the attack of herbivorous insects.

\section{ACKNOWLEDGMENT}

The authors thank the academic Antonio Marcos, Charliane Abreu, Joyce Reis, Luiz Ramos and Maria Conceição by the aid in the data survey.

\section{REFERENCES}

AOYAMA, E. M; LABINAS, A. M. 2012. Características estruturais das plantas contra a herbivoria por insetos. Enciclopédia Biosfera, 15(8): 365-386.

BARÔNIO, G. J. 2012. Leaf hairiness reduces herbivory of 
young and mature leaves of Qualea multiflora Mart. in Brazilian Savanna. Neotropical Biology and Conservation, 2(7). https://doi.org/10.4013/nbc.2012.72.06

BARTIMACHI, A.; NEVES, J.; VASCONCELOS, H. L. 2015. Geographic variation in the protective effects of ants and trichomes in a Neotropical ant-plant. Plant ecology, 8(216): 1083-1090. https://doi.org/10.1007/s11258-0150491-7

CORRÊA, P. G. et al. 2008. Herbivoria e anatomia foliar em plantas tropicais brasileiras. Ciência e Cultura, 60(3): 5457.

KARLEY, A. J.; MITCHELL, C.; BROOKES, C.; et al. 2015. Exploiting physical defence traits for crop protection: leaf trichomes of Rubus idaeushave deterrent effects on spider mites but not aphids. Annals of Applied Biology, 2(168): 159-172. https://doi.org/10.1111/aab.12252

LOPRESTI, E. F.; GROF-TISZA, P.; ROBINSON, M.; et al. 2018. Entrapped sand as a plant defence: effects on herbivore performance and preference. Ecological Entomology, 2(43): 154-161. https://doi.org/10.1111/een.12483

LØE, G.; TORÄNG, P.; GAUDEUL, M.; et al. 2007. Trichome production and spatiotemporal variation in herbivory in the perennial herbArabidopsis lyrata. Oikos, 1(116): 134142. https://doi.org/10.1111/j.2006.0030-1299.15022.x

MANNETHODY, S.; PURAYIDATHKANDY, S. 2018. Trichome micromorphology and its systematic significance in Asian Leucas (Lamiaceae). Flora, (242): 70-78. https://doi.org/10.1016/j.flora.2018.03.007

MEDEIROS RN. Visões da Natureza. In: Sousa IG, Vianna J. M., Meneses R. L. (2015). Cartografias Invisíveis: Saberes e Sentires de Caxias. Caxias: Academia Caxiense de Letras.

OLIVEIRA, E. F.; BEZERRA, D. G.; SANTOS, M. L.; et al. 2017. Leaf morphology and venation of Psidium species from the Brazilian Savanna. Revista Brasileira de Farmacognosia, 4(27): 407413.https://doi.org/10.1016/j.bjp.2017.03.005

PRICE, P W. 2002. Resource-driven terrestrial interaction webs. Ecological Research, 2(17): 241-247. https://doi.org/10.1046/j.1440-1703.2002.00483.x

SALOMÃO, R. de P. et al. 2012. Sistema capoeira classe: uma proposta de sistema de classificação de estágios sucessionais de florestas secundárias para o estado do Pará. Embrapa Amazônia Oriental-Artigo em periódico indexado

(ALICE). http://www.alice.cnptia.embrapa.br/alice/handle/doc/95 0752

SATO, Y; ITO, K.; KUDOH, H. 2017. Optimal foraging by herbivores maintains polymorphism in defence in a natural plant population. Functional Ecology, 2(31): 2233-2243. https://doi.org/10.1111/1365-2435.12937
DA SILVA, L; et al. 2017. Levantamento Bibliográfico: Um Estudo Sobre As Queimadas No Cerrado Brasileiro No Período De 2010 A 2016. Enciclopédia Biosfera, 26(14): 1030-1047. http//doi.org/10.18677/EnciBio_2017B87

PEIXOTO NETO, C. A. A., LIMA, G. P., ARAÚJO, L. P. F., CHAVES, R. A. S., \& SIQUEIRA, G. M. (2016). Biogeography of the central mesoregion of Maranhão (Brazil). Journal of Geospatial Modelling, 1(1), 33-40. https://doi.org/http://dx.doi.org/10.22615/jgm-1.1-5812

R Core Team, 2016. R: A Language and Environment for Statistical Computing. Vienna, Austria, https://www.rproject.org/

TIAN, D.; TOOKER, J.; PEIFFER, M.; et al. 2012. Role of trichomes in defense against herbivores: comparison of herbivore response to woolly and hairless trichome mutants in tomato (Solanum lycopersicum). Planta, 4(236): 1053-1066. https://doi.org/10.1007/s00425-0121651-9

TOZIN, L. R. D. S.; MARQUES, M. O. M.; RODRIGUES, T. M. 2017. Herbivory by leaf-cutter ants changes the glandular trichomes density and the volatile components in an aromatic plant model. AoB PLANTS, 6(9). https://doi.org/10.1093/aobpla/plx057.

\author{
Submissão: 19/10/2018 \\ Aprovado para publicação: 10/01/2019
}

